\title{
A gap analysis of ornithological research in the Brazilian state of Roraima
}

\author{
Marcos Pérsio Dantas Santos ${ }^{1,2}$ \\ ${ }^{1}$ Laboratório de Ecologia e Zoologia de Vertebrados, Instituto de Ciências Biológicas, \\ Universidade Federal do Pará - UFPA, CEP 66075-110, Belém, PA, Brazil \\ ${ }^{2}$ Corresponding author: Marcos Pérsio Dantas Santos, e-mail: marcospersio@uol.com.br
}

SANTOS, M.P.D. A gap analysis of ornithological research in the Brazilian state of Roraima. Biota Neotrop. 12(2): http://www.biotaneotropica.org.br/v12n2/en/abstract?article+bn01312022012

\begin{abstract}
This study analyzes the ornithological data available for the Brazilian state of Roraima, focusing on sampling gaps. All ornithological data collected in Roraima up to the present were collated with the aim of answering the following questions: (a) which sites have been well sampled? (b) Are there are any geographic gaps? (c) What is the current extent of the scientific knowledge of avian diversity in Roraima? (d); Which regions and vegetation types have been well-sampled, and which should be prioritized for future surveys? Ornithological data were obtained from a total of 82 localities, including the Maracá Ecological Station (442 species), Viruá National Park (420 species), Colônia do Apiaú (320 species), Mucajaí (267 species), and Pacaráima (212 species), which were the five sites with the highest species counts. Over the past 20 years, only two localities in Roraima have been added to the list of sites with reliable samples (at least 100 bird species recorded (study skins collected, tape recordings and undocumented field observations), the Viruá National Park and Fazenda Paraense. Five regions of the state were identified as sampling gaps, and should be prioritized in future ornithological surveys: the northwest, on the border with Venezuela and the Brazilian state of Amazonas, the lower Rio Branco between the town of Caracaraí and the mouth of the river, the terra firme forests of the southeast, the savannas of the northeast, on the border with Guyana, and the northern highlands, including montane forest and tepuis.
\end{abstract}

Keywords: amazonia, birds, conservation, rio branco, sampling gaps.

SANTOS, M.P.D. Análise de lacunas da investigação ornitológica no estado de Roraima, Brasil. Biota Neotrop. 12(2): http://www.biotaneotropica.org.br/v12n2/pt/abstract?article+bn01312022012

Resumo: Neste artigo, o esforço de investigação ornitológica no estado de Roraima será investigado utilizando abordagens de análises de lacunas. Basicamente, apresentaremos uma síntese sobre todo o esforço ornitológico feito até o momento em Roraima, visando responder as seguintes questões: (a) quais os locais bem amostrados para aves? (b) quais são as lacunas geográficas de investigação? (c) em que estágio de descobertas está o inventário das espécies de aves em Roraima? (d) quais são os macro-hábitats prioritários para investigação? (e) quais os tipos de vegetação bem investigados e quais os que podem ser classificados como prioritários para investigação? Como resultados, detectamos Oitenta e duas localidades com algum tipo de informação ornitológica. Dentre essas, a Estação Ecológica de Maracá (442 sp), seguido pelo Parque Nacional do Viruá (420 sp), Colônia do Apiaú (320 sp), Mucajaí (267 sp), e Pacaráima (212 sp), são as cinco localidades com maior grau de conhecimento ornitológico dentro do estado. Nos últimos 20 anos apenas duas localidades ornitológicas em Roraima podem ser acrescidas à lista de sítios bem estudados de acordo com o critério de pelo menos 100 espécies registradas (peles, gravações de voz e observações visuais): Parque Nacional do Viruá e a Fazenda Paraense. Cinco áreas são aqui apontadas como lacunas de amostragem da avifauna de Roraima e devem receber prioridade para novos inventários e estudos sobre a avifauna dessa região, são elas: Noroeste do estado, nas áreas junto à fronteira com a Venezuela e divisa com o Estado do Amazonas; Baixo Rio Branco, desde a cidade de Caracaraí à sua foz; Florestas de terra firme no sudeste do Estado; As savanas do nordeste junto à fronteira com a Guiana e as regiões de floresta montana e os tepuis.

Palavras-chave: amazônia, aves, conservação, Rio Branco, análise de lacunas. 


\section{Introduction}

Birds constitute one of the most visible and well-studied zoological groups. With around 9600 different species, birds are found on all continents and oceans, and are generally quite effective indicators of habitat quality (Gill 1995). While new bird species are discovered every year, these additions make up only a very small proportion of the known diversity, contrasting considerably with most other groups of zoological taxa (Marini \& Garcia 2005, Peres 2005). As birds are easily recognized and identified, they constitute an extremely useful group for the quantitative assessment of the sampling effort necessary for the delineation of a region's biological diversity, providing systematic guidelines for biological inventories at national, regional, and local scales (Silva 1995a).

Despite being one of the planet's most ecologically complex and biologically richest regions, much of the Amazon basin is still largely ornithologically unexplored (Oren 2001). Oren \& Albuquerque (1991) analyzed the sampling effort at sites throughout the Brazilian Amazon, considering the collection of 100 specimens as the standard minimum effort required for a reliable sample, and concluded that the vast majority of the region remains virtually unknown, from an ornithological viewpoint. While many ornithological surveys have been conducted since then, raising the total number of reliable inventories to 247 , most of the areas considered then to be poorly sampled by Oren \& Albuquerque (1991) remain undersampled today (Oren 2001, Aleixo 2009). Recently Vale (2007), evaluated how spatial collecting bias affects patterns of bird richness, endemism, and conservation in Amazonia and showed the bias in the location of ornithological collections has a strong effect on bird richness patterns, with the richness at collection localities being significantly higher than expected at random, demonstrating that there are still gaps in the ornithological knowledge of the region and little is known about biodiversity in the Amazon.

The avifauna of Roraima although considered relatively well studied, and the only state in the Brazilian Amazon with a well established list of birds (Santos 2005, Naka et al. 2006), the situation is nevertheless typical of the general Amazonian pattern found by Vale (2007). In fact, Santos (2005) concluded that only a very few, widely-distributed sites have been sampled adequately.

This study investigates the ornithological data available for Roraima and evaluates sampling effort and deficiencies using in a slight modification of the criterion used by Oren \& Albuquerque (1991). The study provides a systematic overview of the sampling effort conducted until now, as an approach to the following questions: (a) which sites have been well sampled? (b) are there are any geographic gaps? (c) what is the current extent of the scientific knowledge of the avian diversity in Roraima? (d) which regions and vegetation types have been well-sampled, and which should be defined as priority areas for future surveys?

\section{Material and Methods}

\section{Study area}

Roraima is the northernmost state of Brazil, covering an area of $225,116 \mathrm{~km}^{2}$ (Figure 1). The state is bounded to the north and northeast by Venezuela, and to the east by Guyana, and is located entirely within the basin of the Rio Branco. There are six distinct

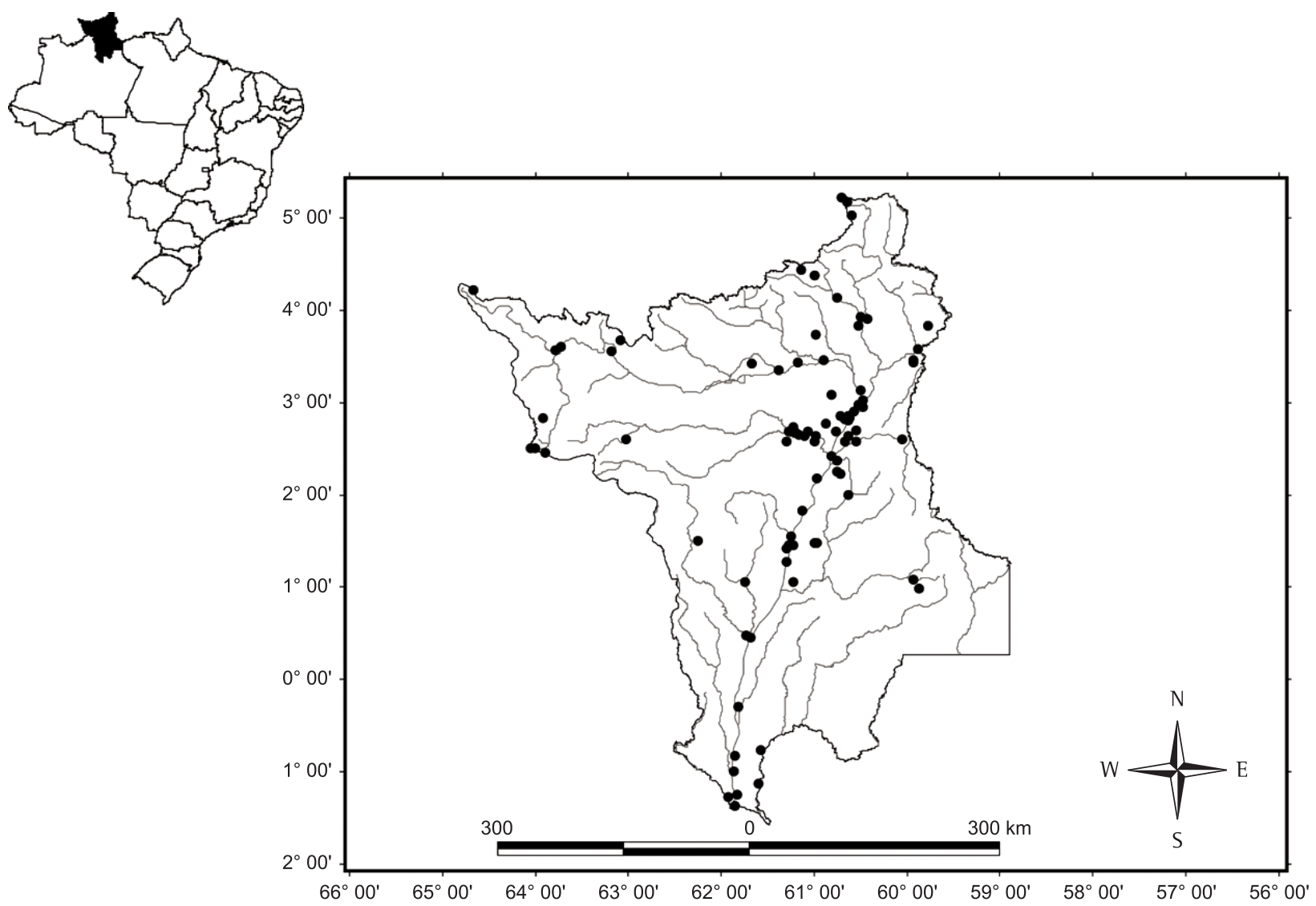

Figure 1. Geographic location of the state of Roraima within Brazil. Circles are all sites at which ornithological surveys have been conducted in the Brazilian state of Roraima. 
altitudinal zones within the state, ranging from lowland areas $(70 \mathrm{~m}$ a.s.l. at the mouth of the Rio Branco), to montane regions (2875 m a.s.l.) at the peak of Mount Roraima (Silva, 1997).

The state also encompasses three distinct climatic regions, $A f$, $A w$, and $A m$ in the Köppen classification system (Superintendência... 1984). In general terms, annual climate is divided in well-defined dry and rainy seasons, with a mean annual temperature of approximately $26{ }^{\circ} \mathrm{C}$ (Barbosa 1997).

Roraima can be divided in two principal ecological domains: the savannas and humid Amazonian terra firme forests. Savannas are found in areas where annual precipitation is less than $1700 \mathrm{~mm}$, most of which is concentrated into a period of 100-130 days (Barbosa 1997). Within these savannas, more arid areas are covered with dry woodlands and gallery forests, while areas with more hydromorphic soil support dense corridors of buriti palms (Mauritia flexuosa), known as "buritizais". Rainforest is found in areas where annual precipitation is never less than $2000 \mathrm{~mm}$. Grasslands ("campinas") and wetland savannas ("campinaranas") are found on sandy soils within these rainforest formations.

\section{Data analyses}

All localities where ornithological fieldwork has been conducted were identified from the database available in Santos (2005). This study includes all sites mentioned by Paynter \& Traylor (1991), in addition to those identified through a bibliographic review (Appendix 1), and the localities visited by Santos (2005) and Naka et al. (2006). The geographic coordinates were obtained from Paynter \& Traylor (1991), Vanzolini (1992), and Santos (2005).

Differently the criterion used by Oren \& Albuquerque (1991) (100 specimens collected), we used the criterion of 100 recorded species to consider a locality as well sampled. We recognize as a valid record three basic types of information available in the literature, museums and field trips: skins, tape recordings and observations. Therefore the ornithological localities of Roraima were selected using all types of records available for each locality (skins, tape recordings, observations). Based on these data, the sites were classified in one of the following categories: (a) some ornithological data available; (b) at least 50 species recorded; and (c) more than 100 species recorded. The sites classified according to this scheme were mapped within the state of Roraima using ArcGis 9.3, in order to visualize the distribution of sampling effort within the state. This map was superimposed on the IBGE (Instituto... 1993) vegetation map for the state, to allow the visualization of sampling effort according to habitat, on which the definition of research priorities was based.

To evaluate the current level of inventory completeness of the avifauna of Roraima, cumulative species curves were prepared and analyzed using the Excell software. These curves are widely used in ecological studies, and indicate the cumulative number of species recorded over time. The curve should reach an asymptote as the number of species recorded approaches the total number existing within the area surveyed. For this analysis, a database was prepared, which included the name of each species and the year in which it was first recorded in Roraima.

Silva \& Santos (2005) found that the rate at which species are recorded may vary considerably among habitat types. Therefore, separate curves were prepared for three major ecological groups, defined according to their dependence on forested habitats: (1) independent - species that are only found in open (savanna) formations; (2) semi-dependent - species that occur in both open vegetation and forest; and (3) dependent - species found essentially in forested habitats (terra firme forest, várzea, and campinarana). The objective of this analysis was to provide a more systematic baseline for the evaluation of research priorities. The three groups were based on the classifications of habitat use provided by Silva (1995b) and Sick (1997), supplemented by Field observations by the author.

The taxonomic classification of the bird species followed CBRO (Comitê... 2011).

\section{Results}

The general species accumulation curve for bird species in Roraima (Figure 2) indicates a long period of stagnation during the initial years of exploration of the region, with a first spurt of records at the beginning of the twentieth century, as a consequence of the first major expeditions along the Rio Branco. During this period, however, the curve grew in steps, coinciding with isolated surveys, rather than any continuous or prolonged research effort. A second spurt in the number of species recorded was observed only in the 1980s, and resulted from major expeditions to Maracá Island, Colônia do Apiaú, Boa Vista, and the Brazilian-Venezuelan border. Despite the increase in the number of species catalogued during recent years, the general species accumulation curve does not show a clear tendency towards stabilization (nonasymptotic), indicating that the total number of bird species occurring in Roraima is still considered to be an underestimate (Figure 2).

The cumulative species curves for species not linked to forested habitats (independent and semi-independent) grew slowly in the first years of exploration, and continued to increase only gradually in subsequent years (Figure 2). For the forest-dependent group, by contrast, the curve has grown rapidly throughout the period, with no clear tendency for stabilization. Considering the 28 species added to the inventory of Roraima by Santos (2005), 22 (78.57\%) are forest-dependent, while four $(14.28 \%)$ are independent, and only two $(7.14 \%)$ are semi-dependent. Of this total, $46.15 \%$ are nonpasseriformes, $46.15 \%$ are suboscines passerines, and $7.70 \%$ are oscines passerines.

Ornithological data are available from 82 localities in the state of Roraima (Figure 1; Appendix 1). Of these sites, the richest in species is the Maracá Ecological Station, with a total of 442 species, followed by the Viruá National Park, with 420 . The next most prominent sites are Colônia do Apiaú (320 species), Mucajaí (267 species), and Pacaráima (212 species). However, 100 or more species were recorded at only $18(21.1 \%)$ of the 82 sites, which are mainly distributed in and around Boa Vista or Maracá Island (Figure 3). Even if the standard is set at a minimum of 50 species, the number of sites is still only 31 , i.e. only $35.4 \%$ of the total number of sites (Figure 4 ).

Oren \& Albuquerque (1991) identified only three localities in Roraima at which the avifauna had been surveyed according to their criterion of the collection of at least 100 specimens. Based on this criterion, however, seven additional sites (Forte de São Joaquim, Boa Vista, Mucajaí, Serra da Lua, Colônia do Apiaú, Maracá Ecological Station, and Vila Sorocáima) could have been included in this total. Twenty years later, only two additional localities can be added to this list, the Viruá National Park and the Fazenda Paraense, both of which were surveyed by Santos (2005) (Figure 5).

In relation to the different types of vegetation found in Roraima (Table 1), no ornithological data whatsoever are available for four of the 13 categories. These include three types of savanna, and a campinarana formation of the lower Rio Branco (Figure 6).

\section{Discussion}

The shape of the historic species accumulation curve for the avifauna of Roraima suggests that many additional species have yet to be recorded, especially in forested habitats, rather than more open environments. This conclusion is also supported by the fact that a large number of bird species with an ample 
Santos, M.P.D.

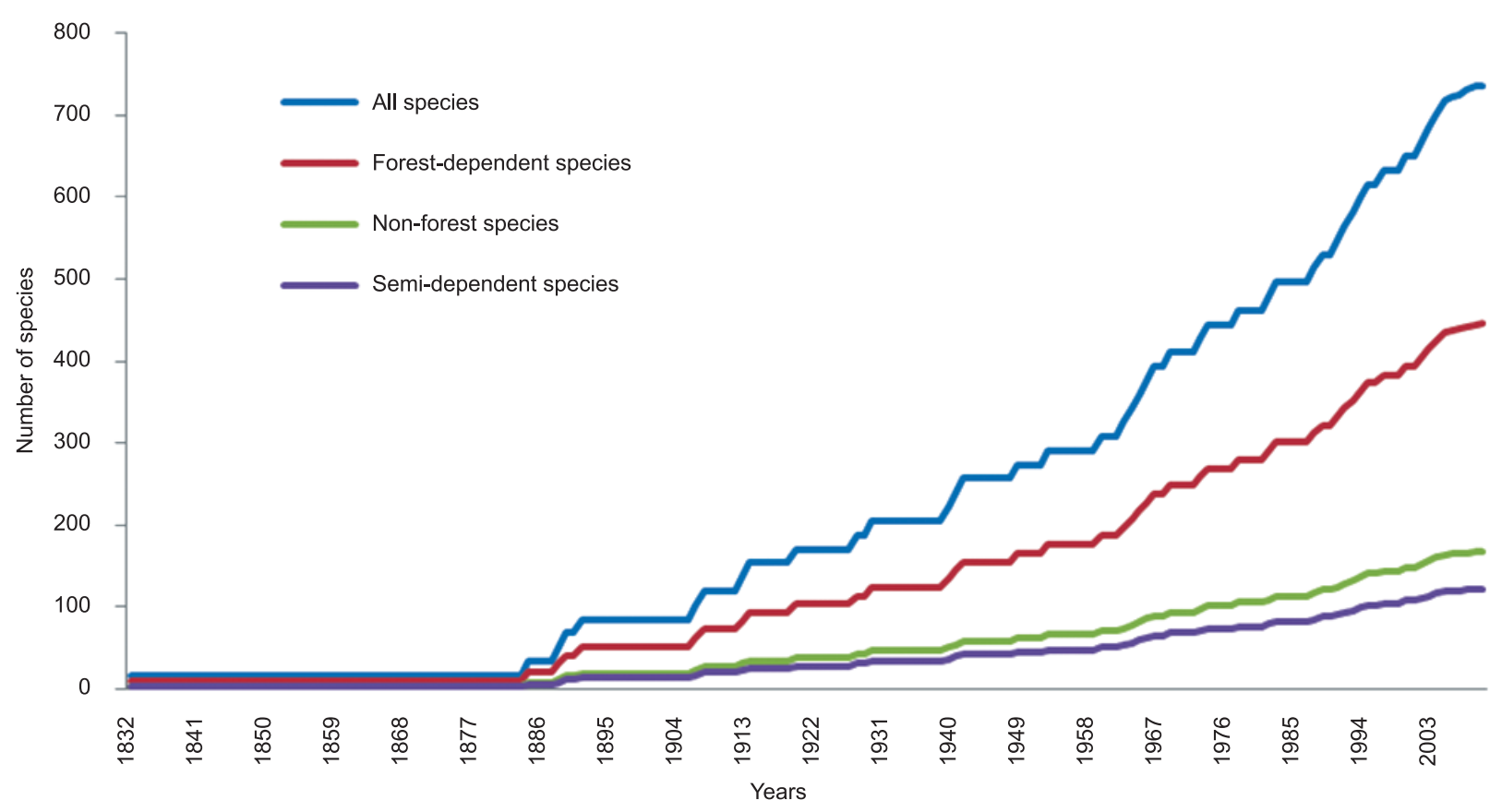

Figure 2. Historic cumulative species curves for the avifauna of the Brazilian state of Roraima.

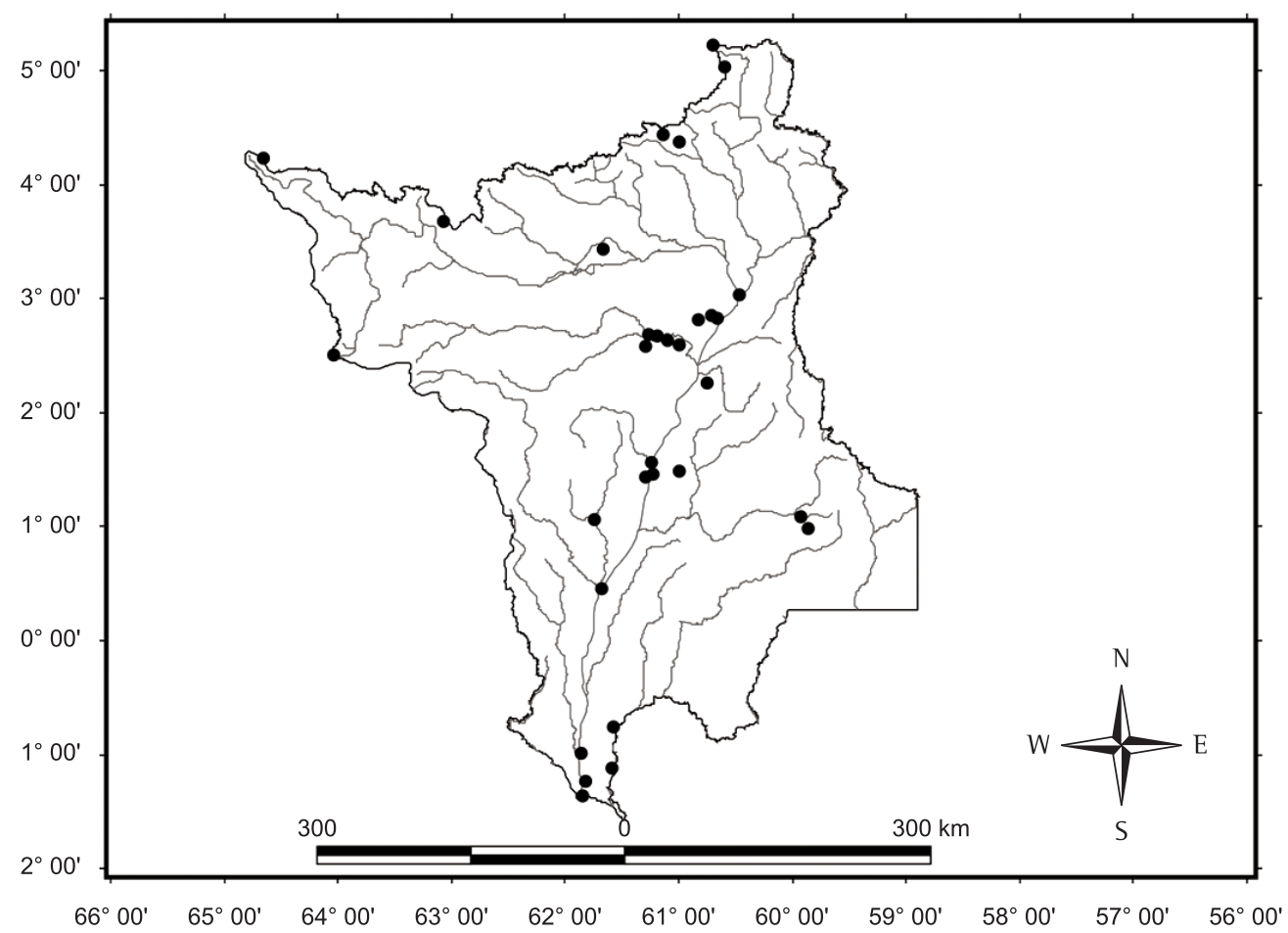

Figure 3. Sites at which at least 50 bird species have been recorded in the Brazilian state of Roraima.

distribution in northern South America and records from southern Venezuela and Guyana, have not yet been observed in Roraima (Naka et al., 2006). These species include Amazona autumnalis, Celeus undatus, Phylloscartes virescens, Lophotriccus vitiosus, Lurocalis semitorquatus, Myrmeciza pelzelni, Neopipo cinnamomea, Dichrozona cincta, Iodopleura isabellae, Phlegopsis nigromaculata,
Phoenicircus nigricollis, Certhiasomus stictolaemus, Haematoderus militaris, Lepidothrix serena, Notharchus ordii, Philydor erythrocercum, Lamprospiza melanoleuca, Malacoptila fusca, Philydor erythropterum, and Selenidera nattereri.

The majority of the sites in Roraima from which ornithological data are available have been sampled in only a minimal fashion, and 


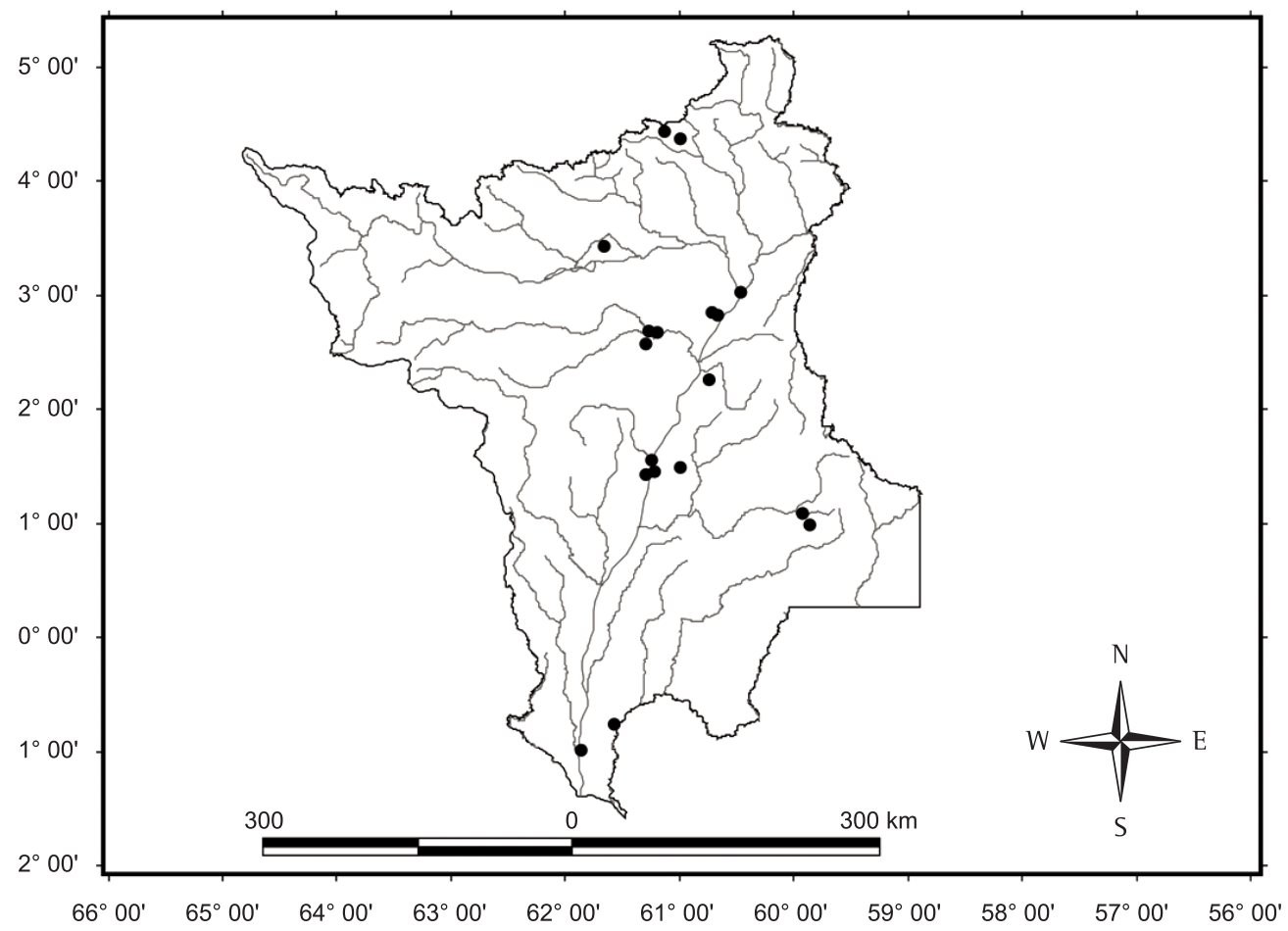

Figure 4. Sites at which at least 100 bird species have been recorded in the Brazilian state of Roraima.

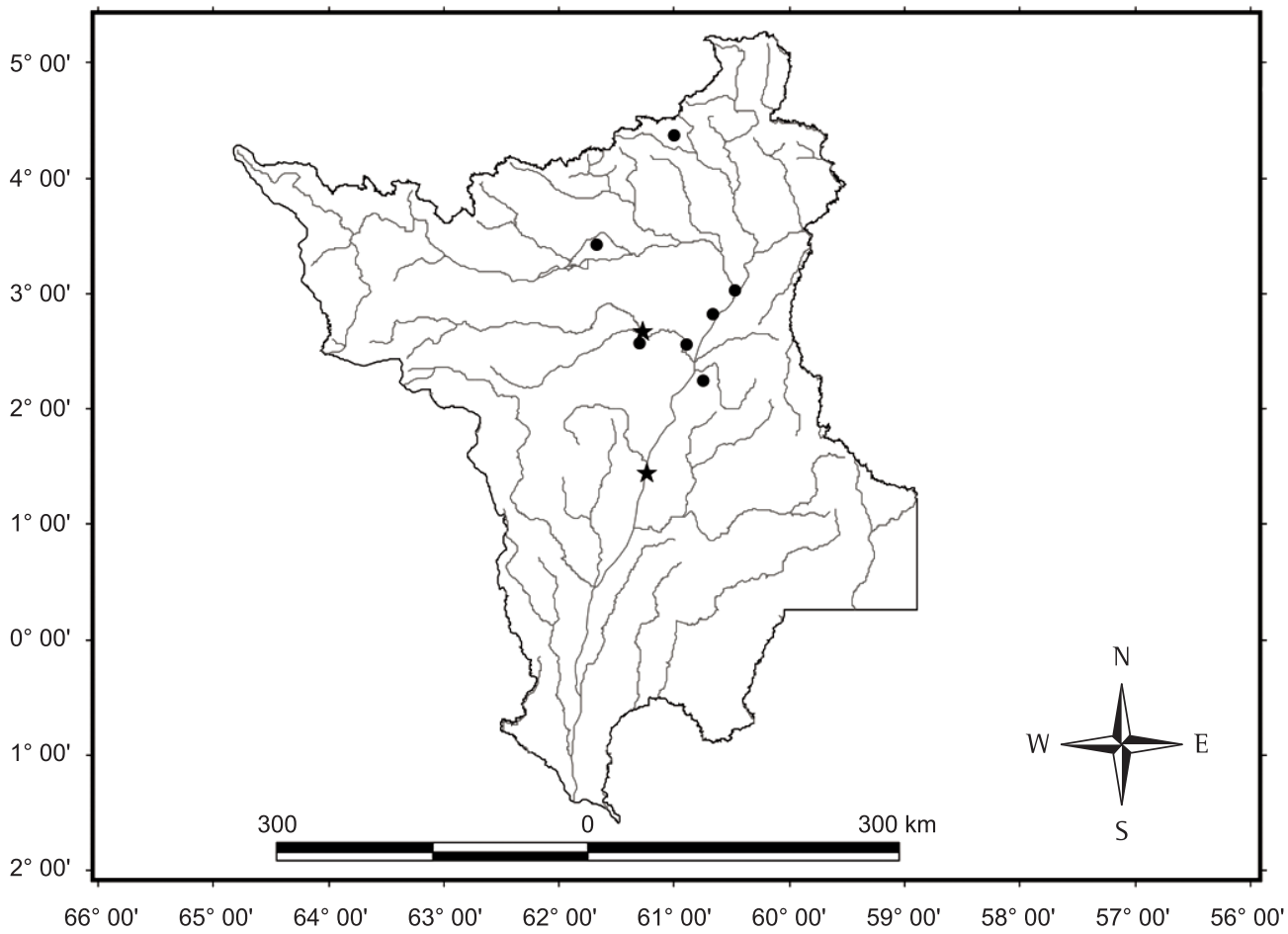

Figure 5. Sites in Roraima at which at least 100 bird specimens have been collected prior to (black circles) and after (black stars) the study of Oren \& Albuquerque (1991).

considerable gaps can be observed within the state (Figure 3). Overall, only 18 of the 82 sites can be considered to have been relatively well sampled, according to the criterion adopted in the present study (at least 100 species recorded - skins, tape records and observations).
Worse still, most of these sites are located in easily-accessible areas, mainly along the Rio Branco and in the vicinity of Boa Vista. This is, in fact, typical of the sites at which ornithological studies have been conducted throughout the Amazon basin (Haffer 1974, Oren \& 


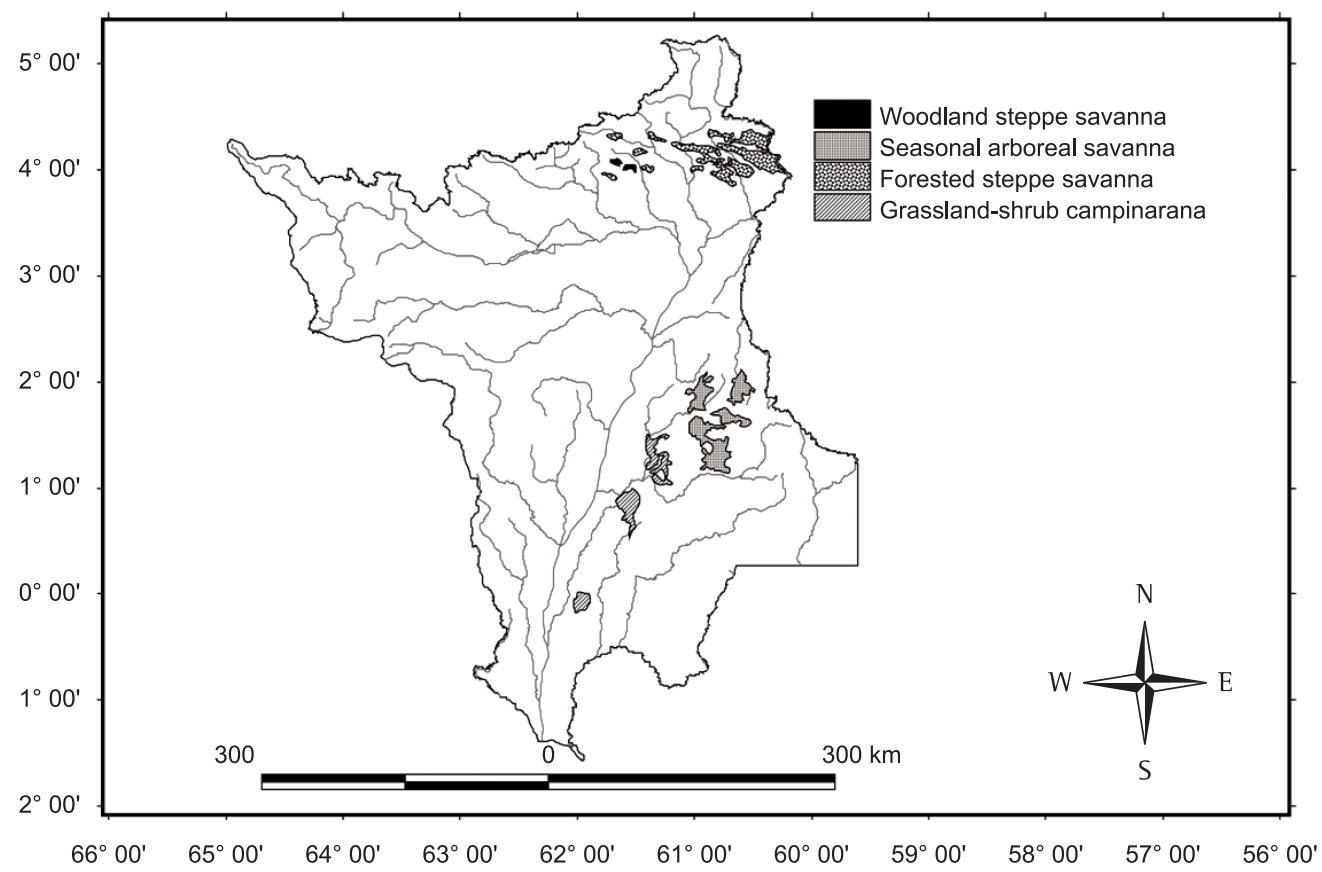

Figure 6. Vegetation types in Roraima for which no ornithological data are available.

Albuquerque 1991). Silva (1995a) recorded a similar pattern in the Cerrado savannas of central Brazil, where $70 \%$ of the region remains poorly-studied by ornithologists. Overall, then, the scenario recorded for Roraima twenty years ago by Oren \& Albuquerque (1991) has changed very little, and the same lacunas in ornithological sampling are apparent in the present study.

These lacunas include five main areas, which should be given the maximum priority for future ornithological surveys:

a. Northwestern corner of the state, on the border with Venezuela and the Brazilian state of Amazonas. This region is dominated by well-preserved terra firme and submontane forests;

b. Lower Rio Branco, between the town of Caracaraí and the mouth of the river. The várzea forests, campinas, and campinaranas that dominate this landscape are extremely diverse in biological terms, and may have an avifauna related to those of the várzeas of the Amazon and the igapós of the Rio Negro, which would include many species not yet recorded in Roraima;

c. Terra firme forests of the southeast of the state, on the border with Guyana and the Brazilian state of Pará. It seems likely that many of the bird species recorded in the region of Manaus by Cohn-Haft et al. (1997) may also occur in this area, further increasing the state's species list;

d. The northeastern savannas, on the border with Guyana. While this region is relatively accessible, it is still poorly-known from and ornithological viewpoint, and probably contains many species found only in the savannas of northern South America (Aratinga solstitialis, Synallaxis kollari, Campylorhynchus griseus);

e. The montane forests and tepuis (isolated plateaus) of the northern extreme of the state on the border with Venezuela. Some areas are especially important, such as the slopes of Mount Roraima, Pacaráima, and tepuis such as Tapequén, Surucucu, and Uafaranda.

The least-studied vegetation types in Roraima included three savanna categories (seasonal woodland, forested steppe, and
Table 1. Number of ornithological studies conducted by vegetation type in the Brazilian state of Roraima.

\begin{tabular}{lc}
\hline \multicolumn{1}{c}{ Type of vegetation } & Number of localities $(\mathbf{N}=\mathbf{8 2})$ \\
\hline Seasonal arboreal savanna & 0 \\
Seasonal parkland savanna & 13 \\
Seasonal grassland-shrub savanna & 9 \\
Forested steppe savanna & 0 \\
Woodland steppe savanna & 0 \\
Parkland steppe savanna & 1 \\
Rainforest campinarana & 2 \\
Woodland campinarana & 3 \\
Grassland-shrub campinarana & 0 \\
Sub-montane rainforest & 23 \\
Montane rainforest & 10 \\
Lowland rainforest & 24 \\
Seasonal, semi-deciduous Forest & 1 \\
\hline
\end{tabular}

woodland steppe) and grassland-shrub campinarana (Table 1). No data whatsoever are available on the avifauna of these areas. With the exception of the forested steppe, which is located within an area dominated by conflicts between settlers and indigenous populations, the lack of data from these savannas may be due to their relatively small size, especially considering that they are all located in the vicinity of highways, and are thus relatively easily accessible. Similar factors may also account for the lack of studies in the campinarana, which is close to the BR 174 highway, but also covers a relatively small area.

Silva (1995a) has suggested that surveys in poorly-known regions should initially prioritize areas of highly anthropogenically impacted, considering the relatively high probability of local extinctions in such areas. From this perspective, the five lacunas identified above, together with the vegetation classes that lack data, can be ranked 
according to their relative vulnerability to anthropogenic pressures. The regions $\mathrm{a}, \mathrm{b}$, and $\mathrm{e}$ in the north and northwest of the state and on the lower Rio Branco are relatively well preserved and isolated from human impacts. By contrast, region $\mathrm{c}$, in the southeast of the state, has suffered extensive deforestation due to the transformation of natural habitats into pastures and agricultural fields, while vast areas of the savannas and gallery forests of region d, in the northeast, have been converted into rice and soybean plantations. This situation can be even more worrying if we imagine in local extinctions caused by fragmentation.Studies with birds in the north of Manaus showed that the process of forest fragmentation produced sequential extinctions in a time interval of 20 years and that over $30 \%$ of species went extinct in 1-ha fragments, compared to about 5\% in 100 ha fragments (Stouffer et al. 2009). Bird et al. (2011) observed that the incorporating projected deforestation into avian threat assessments increases the number of species qualifying as threatened on the IUCN Red List considerably and provides a more accurate reflection of the extinction risk facing species in the region. These data reinforce the need to carry out inventories in forest areas considered "bird gap" in the state of Roraima.

Overall, the lacunas identified in the present study can be grouped into two main classes of priority for ornithological inventory: (1) areas of maximum priority, with high levels of habitat alteration, and (2) areas of secondary priority, with relatively low levels of habitat modification, but few ornithological data. The first group includes the forests of the southeast of the state, and the savannas of the northeast. The second group encompasses the forests of the northwest, the campinaranas and flooded forests of the lower Rio Branco, and the highlands and tepuis of the northern border with Venezuela.

\section{Acknowledgements}

I am grateful to Fundação o Boticário de Proteção a Natureza (FBPN - 050820012), WWF-Brazil - Ford Foundation (CSR 2432001) and The Nature Conservancy - and TNC-Brasil (TNC 006/03) for their financial support of the surveys in Roraima. The Zoology Department of the Goeldi Museum (CZO/MPEG) in Belém also provided essential support for the development of this project. I am grateful to the Brazilian National Research Council (CNPq) for provided a doctoral stipend, to José Maria Cardoso da Silva for the supervision of my dissertation, and to Stephen Ferrari for his revision of the English text. Finally, I would like to thank the Chico Mendes Institute for Conservation and Biodiversity (ICMBio) for logistic support and granting me a license for the collection of specimens.

\section{References}

ALEIXO, A. 2009. Knowledge gaps, research priorities, and future perspectives on bird conservation in the Brazilian Amazon. In Áreas importantes para a Conservação das Aves no Brasil. Parte II - Amazônia, Cerrado e Pantanal (A.C. De Luc, P.E. Devele, G.A. Benck, J.M. Goerck, orgs.). SAVE Brasil, São Paulo, p.55-69.

BARBOSA, R.I. 1997. Distribuição das chuvas em Roraima. In Homem, Ambiente e Ecologia no Estado de Roraima (R.I. Barbosa, E.J.G. Ferreira \& E.G Castellón, eds.). INPA, p.325-335.

BIRD, J.P., BUCHANAN, G.M., LEES, A.C., CLAY, R.P., DEVELEY, P.F., YE'PEZ, I. \& BUTCHART, S.H.M. 2011. Integrating spatially explicit habitat projections into extinction risk assessments: a reassessment of Amazonian avifauna incorporating projected deforestation. Divers. Distrib.18(3):1-9.

BORGES, S.H. 1994. Listagem e novos registros de aves para a região de Boa Vista, Roraima, Brasil. Bol. Mus. Para. Emilio Goeldi, Zool. 10(2):191-202.
COMITÊBRASILEIRODEREGISTROS ORNITOLÓGICOS-CBRO. 2011. Lista das aves do Brasil. 10. ed. CBRO. http://www.cbro.org.br (último acesso em 15/11/2011).

COHN-HAFT, M., WHITTAKER, A. \& STOUFFER, P. 1997. A new look at the "species-poor" Central Amazon: The avifauna north of Manaus, Brazil. Ornithol. Monogr. 48:205-235.

DICKERMAN, R.W. \& PHELPS, W.H.J. 1982. An annotated list of the birds of Cerro Urutaní on the border of Estado Bolívar, Venezuela, and Territorio Roraima, Brazil. Am. Mus. Novit. 2732:1-20.

FORRESTER, B.C. 1995. Brazil's northern frontier sites: in search of two Rio Branco endemics. Cotinga 3:51-53.

GILL, F.B. 1995. Ornithology. 2nd. ed. W.H. Freeman and Co, New York.

MARINI, M.A. \& GARCIA, F.I. 2005. Conservação de aves no Brasil. Megadiversidade 1(1):95-102.

HAFFER, J. 1974. Avian speciation in tropical South America. With a systematic survey of the toucans (Ramphastidae) and jacamars (Galbuliae). Nuttall Ornithological Club, Cambridge, v.14, p.1-390.

HELLMAYR, C.E. \& CONOVER, B. 1949. Catalogue of birds of the Americas. Publ. / Field Mus. Nat. Hist., Zool. Ser. 13(Part 1(4)):634. http://dx.doi.org/10.5962/bhl.title.2847

INSTITUTOBRASILEIRODEGEOGRAFIAEESTATÍSTICA-IBGE. 1993. Mapa da vegetação brasileira. Rio de Janeiro.

NAKA, L.N., COHN-HAFT, M., MALLET-RODRIGUES, F., SANTO., M.P.D. \& TORRES, M.F. 2006. The avifauna of the Brazilian state of Roraima: bird distribution and biogeography in the Rio Branco basin. Rev. Bras. Ornitol. 14:197-238.

OREN, D.C. 2001. Biogeografia e conservação de aves na região amazônica. In Biodiversidade na Amazônia Brasileira: Avaliação e ações prioritárias para a conservação, uso sustentável e repartição de benefícios (J.P.R. Capobianco, A. Veríssimo, A. Moreira, D. Sawyer, I. Santos \& L.P. Pinto, eds.). Editora Instituto Socioambiental e Estação Liberdade, São Paulo, p.97-109.

OREN, D.C. \& ALBUQUERQUE, G. 1991. Priority Areas for New Avian Collections in Brazilian Amazonian. Goeldiana, Zool. 6:1-11.

PAYNTER, R.A.J. \& TRAYLOR, M.A. 1991. Ornithological Gazetteer of Brazil. Museum of Comparative Zoology, Cambridge, 2 v. http://dx.doi. org/10.5962/bhl.title.14635

PEBERDY, P.S. 1941. Report on the progress and field work of the Briths Guiana Museums 20th april 1939 to 31st december 1940. Carneguie Building, Georgetown. 37p. Report of the British Guiana Museum.

PELZELN, A. VON. 1868-1870. Zur Ornithologie Brasiliens. Resultate von Johann Natterers Reisen in den Jahren 1817 bis 1835. Pichler's Witwe \& Sohn, Wien, 3 v., 538p., 2 maps.

PERES, C.A. 2005. Porque precisamos de megareservas na Amazônia. Megadiversidade 1:174-180.

PHELPS, W.H.J. 1973. Adiciones a las listas de aves de sur America, Brasil Y Venezuela y notas sobre aves venezolanas. Bol. Soc. Venez. Cienc. Nat. 30:23-40.

PHELPS, W.H. \& PHELPS, W.H.J. 1947. Description de seis aves nuevas de Venezuela y notas sobre veinticuatro adiciones a la avifauna del Brasil. Bol. Soc. Venez. Cienc. Nat. 71:53-74.

PHELPS, W.H. \& PHELPS, W.H.J. 1962. Cuarentinueve aves nuevas para la avifauna brasilena del Cerro Uei-Tepui (Cerro del Sol). Bol. Soc. Venez. Cienc. Nat. 101(23):32-39.

PINTO, O.M.O. 1966. Estudo crítico e catálogo remissivo das aves do Território Federal de Roraima. Cad. Amazônia 8:1-176.

SANTOS, M.P.D. 2005. Avifauna do estado de Roraima: Biogeografia e Conservação. Tese de doutorado, Universidade Federal do Pará, Belém, 589p.

SHATTUCK, G.C. 1926. Observations on the Rio Branco, the Uraricoera and Parima rivers. In Medical report of the Hamilton Rice seventh expedition to the Amazon, in conjunction with the department of tropical medicine of Havard University, 1924-1925. Harvard University Press, Cambridge. Contributions from the Harvard Institute for Tropical Biology and Medicine, v.4, p.261-283. 
SICK, H. 1965. Jacus (Penelope) da região amazônica (Aves, Cracidae). Pap. Avulsos Zool. 17:9-16.

SICK, H. 1997. Ornitologia Brasileira: uma introdução. Nova Fronteira, Rio de Janeiro.

SILVA, E.L.S. 1997. A vegetação do estado de Roraima. In Homem, Ambiente e Ecologia no Estado de Roraima (R.I. Barbosa, E.J.G. Ferreira \& E.G Castellón, eds.). INPA, p.401-415.

SILVA, J.M.C. 1995a. Avian inventory of the cerrado region, South America: implication for biological conservation. Bird Conserv. Int. 5:291-304.

SILVA, J.M.C. 1995b. Biogeographic analysis of the South American Cerrado avifauna. Steenstrupia 21:49-67.

SILVA, J.M.C. 1998. Birds of the Ilha de Maracá. In Maracá: The biodiversity and environment of an Amazonia Rainforest ( M. William \& J. Ratter, eds.). John Wiley \& Sons, Chichester, p.211-229.

SILVA, J.M.C. \& SANTOS, M.P.D. 2005. A Importância relativa dos processos biogeográficos na formação da avifauna do Cerrado e de outros biomas brasileiros. In Biodiversidade: Ecologia e Conservação do Cerrado (A.O. Scariot, J.C.S. Silva \& J.M. Felfili, eds.). Brasília, p.220-233.
STOTZ, D.F. 1997. Levantamento preliminar da avifauna em Roraima. In Homem, Ambiente e Ecologia no Estado de Roraima (R.I. Barbosa, E.J.G. Ferreira \& E.G Castellón, eds.). INPA, p.581-608.

STOUFFER, P.C., STRONG, C. \& NAKA, L.N. 2009. Twenty years of understorey bird extinctions from Amazonian rain forest fragments: consistent trends and landscape-mediated dynamics. Divers. Distrib. 15:88-97 http://dx.doi.org/10.1111/j.1472-4642.2008.00497.x

SUPERINTENDÊNCIA DO DESENVOLVIMENTO DA AMAZÔNIA - SUDAM. 1984. Atlas Climatológico da Amazônia. SUDAM, Belém. Publicação n.39.

VALE, M.M. 2007. Avian distribution patterns and conservation in Amazonia. Dissertation of doctoral, Duke University, Duke, 157p. http://dx.doi. org/10.1016/j.jradnu.2007.07.004

VANZOLINI, P.E. 1992. A supplement to the Ornithological Gazetteer of Brazil. Museu de Zoologia, Universidade de São Paulo, São Paulo.

ZIMMER, J.T. 1937a. Studies of Peruvian Birds. No. 27. Notes on the genera Muscivora, Tyrannus, Empidonomus, and Sirystes, with further notes on Knipolegus. Am. Mus. Novit. 962:1-28.

ZIMMER, J.T. 1937b. Studies of Peruvian Birds. No. 28. Notes on the genera Myiodynastes, Conopias, Myiozetetes, and Pitangus. Am. Mus. Novit. 963:1-28. 


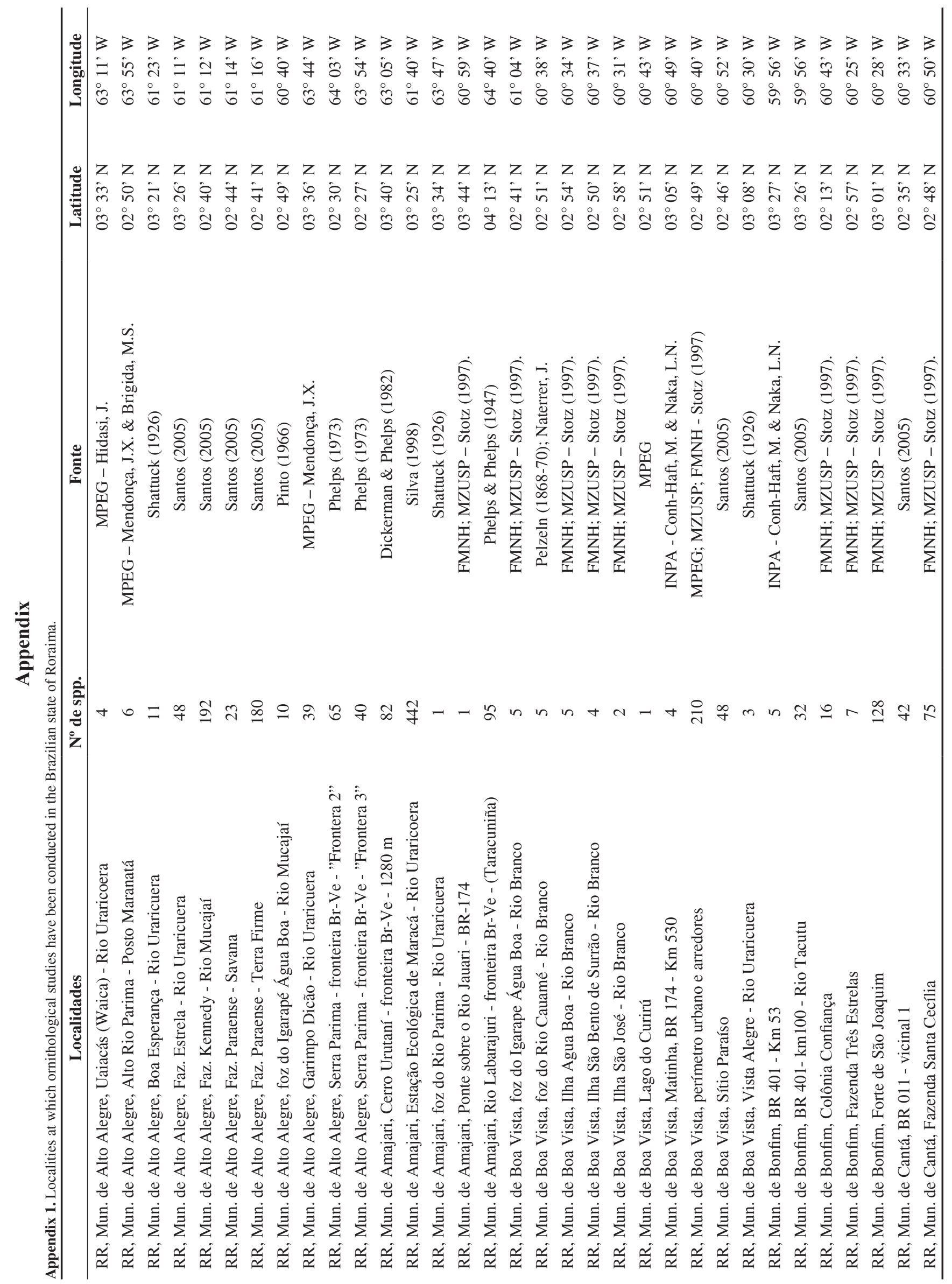


Santos, M.P.D.

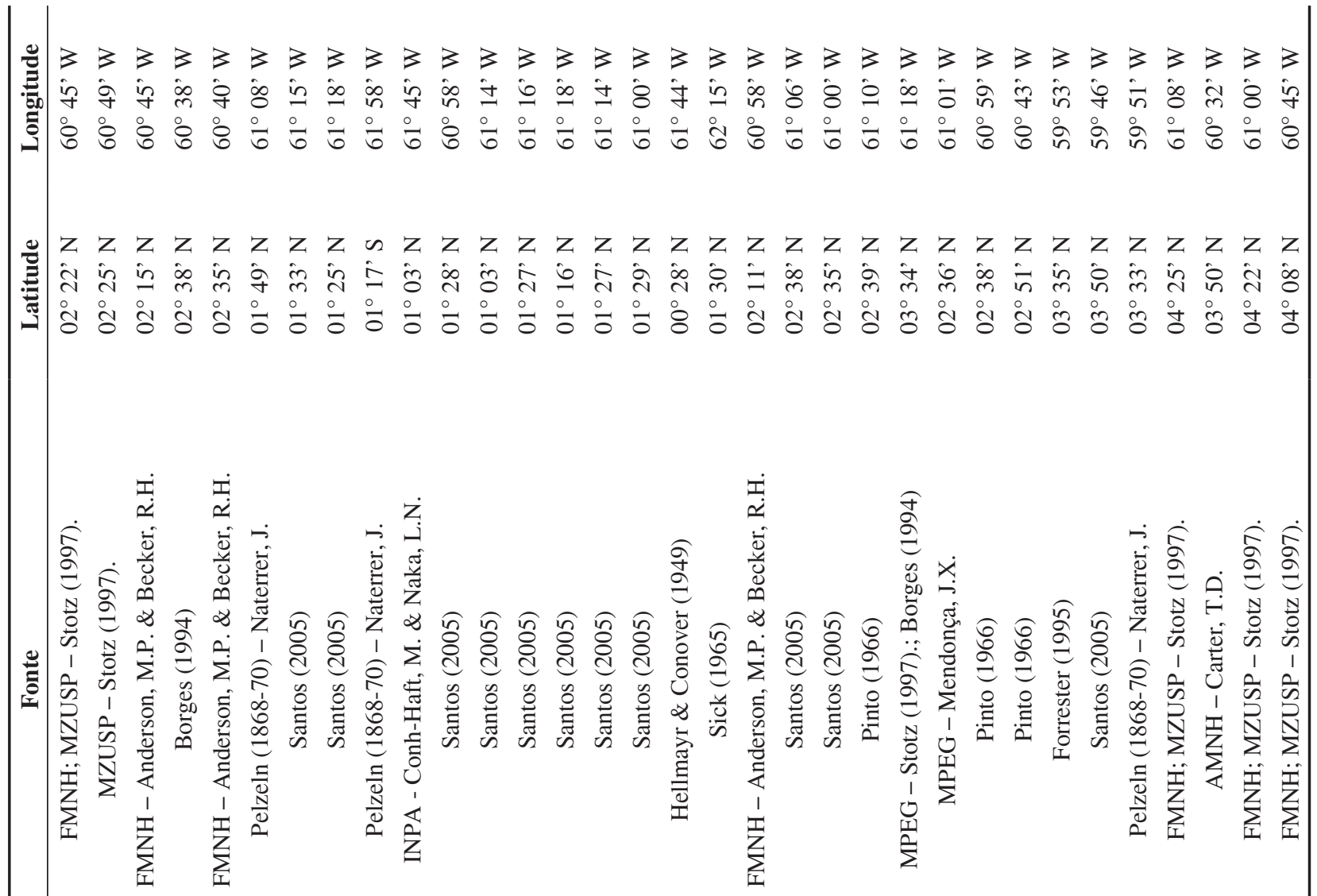

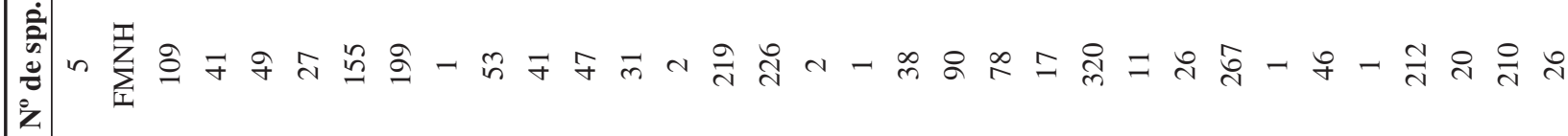

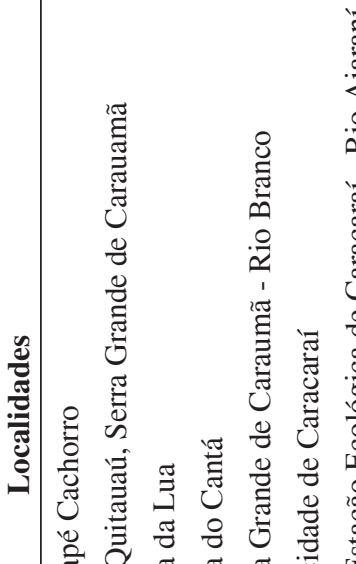

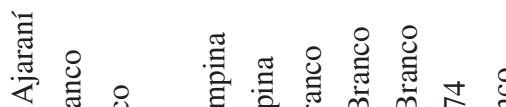

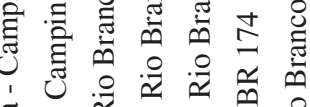

\%

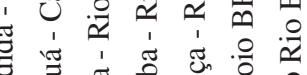

雪

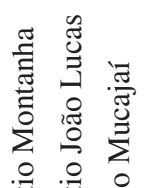

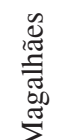

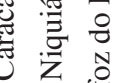

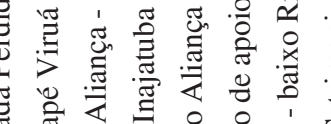

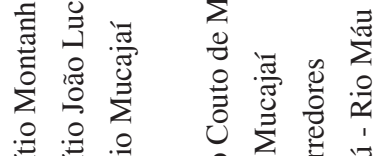

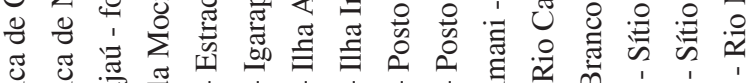

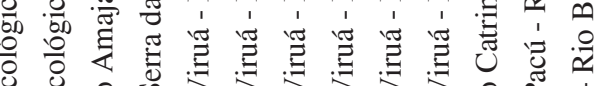

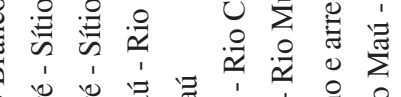




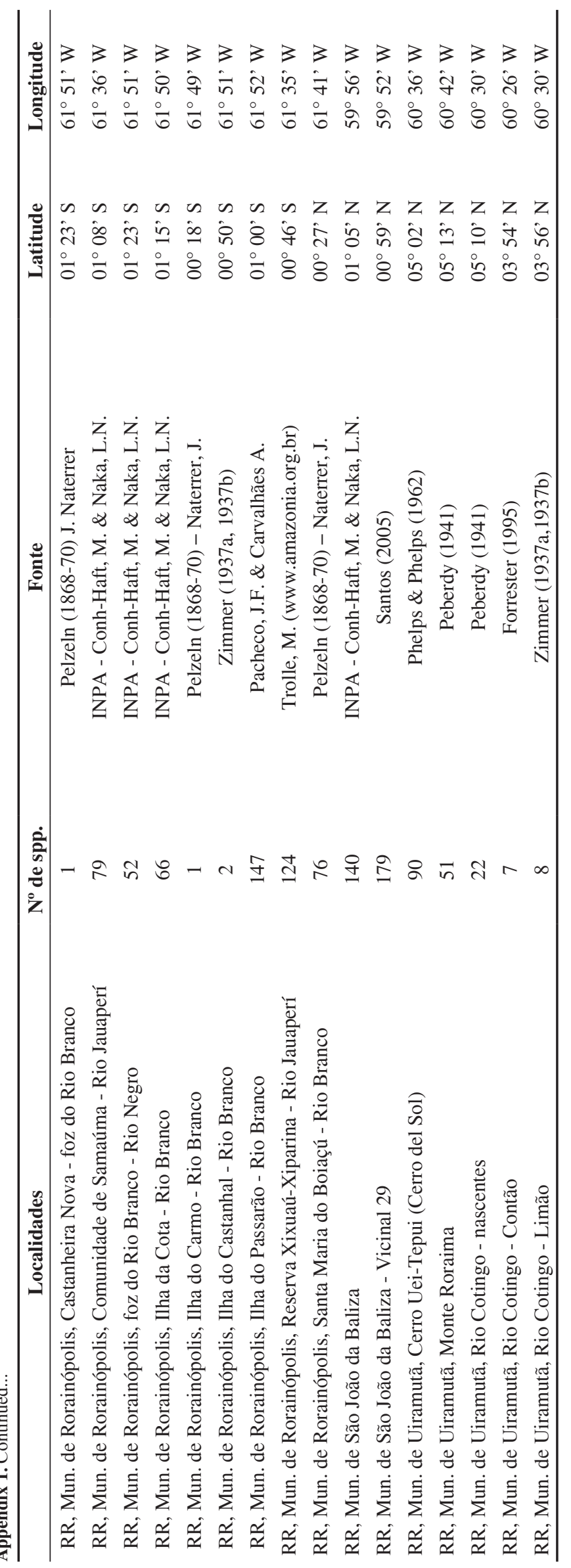

